\title{
脳動静脈奇形に対する血管内および直達併用手術の経験
}

\begin{tabular}{|c|c|c|c|c|c|}
\hline 榊 & 寿右, 宮本 & 和典, ${ }^{1}$ 竹嶋 & 俊一, & 黒川䊽 & 申一郎 ${ }^{1}$ \\
\hline 冨永 & 正夫, 西谷 & 昌也, , 森本 & 哲也, & 角田 & 茂 ${ }^{1}$ \\
\hline 岩崎 & 聖2, 中川 & 裕之, 田岡 & 俊昭, & 滝 & 和郎 3 \\
\hline 田 & $夫^{4}$ & & & & \\
\hline
\end{tabular}

\section{Direct Surgery for Cerebral Arteriovenous Malformation After Superselective Intravascular Embolization}

Toshisuke Sakaki, M.D., ${ }^{1}$ Kazunori Miyamoto, M.D. ${ }^{1}$ Toshikazu TaKeshima, M.D. ${ }^{1}$

Shinichiro Kurokawa, M.D., ${ }^{1}$ Masao Tominaga, M.D., ${ }^{1}$ Masaya Nishitani, M.D., ${ }^{1}$

Tetsuya Morimoto, M.D., ${ }^{1}$ Shigeru TsunOda, M.D., ${ }^{1}$ Satoshi Iwasaki, M.D., ${ }^{2}$

Hiroyuki Nakagawa, M.D., ${ }^{2}$ Toshiaki TAOKA, M.D., ${ }^{2}$ Waro TAKI, M.D., ${ }^{3}$

and Hiroo Iwata, M.D. ${ }^{4}$

${ }^{1}$ Departments of Neurosurgery and ${ }^{2}$ Radiology, Nara Medical University, Kashihara,

${ }^{3}$ Department of Neurosurgery, Kyoto University, Kyoto, and ${ }^{4}$ Department of

Surgical Research, National Cardiovascular Center, Suita, Japan

Summary : Embolization is used as a radical therapy, as well as an adjunctive therapy with surgery for cerebral arteriovenous malformations (AVM). Eight patients underwent endovascular embolization and then surgical resection for cerebral AVM. In two cases, although AVM was embolized completely on the digital subtraction angiographical (DSA) evaluation, slight arterial blood filling into the nidus of AVM was observed on the surgical exploration. Postoperative computerized tomography $(\mathrm{CT})$ demonstrated extent infarction area which was seemed secondary to occlusion of feeding arterial trunk due to retrograde thrombosis from nidus, although new neurological deficits were not recognized because of infarction in the non-dominant temporal lobe. In three cases, embolization of AVM was partial, because catheterization into the all feeding arteries was difficult. But, in two cases who had AVM in the right temporal and in the left occipital lobe respectively, surgical removal of AVM was performed completely without excessive hemorrhage. In another case who had AVM in the corpus callosum, although AVM was smoothly removed, the patient died of postoperative pulmonary embolism. In three cases, AVM could not be embolized at all because of impossible catheterization into feeding arteries. Histological findings of removed AVM which was completely embolized angiographically demonstrated that embolus mainly existed in the nidus and draining veins, and existence of blood around the embolus in these vessels.

These histological findings and the our intraoperative obseravation of slight arterial blood inflow into the nidus in the angiographically complete embolized AVMs imply that AVM should be removed surgically, even if it is embolized sufficiently. We must not forget that angiographical complete embolization of AVMs may provoke infarction of the normal brain around them, although they can be removed surgically without difficulty by the embolization.
Key words :

- cerebral arteriovenous malformation

- intravascular surgery

- surgical treatment

- iatrogenic cerebral infarction

1奈良県立医科大学 脳神経外科, ${ }^{2}$ 同 放射線科, ${ }^{3}$ 京都大学 脳神経外科, ${ }^{4}$ 国立循環器病センター 実験治療開発部

(受稿日 1992.8.24)[連絡先：干634 橿原市四条町 840 奈良県立医科大学 脳神経外科 榊 寿右] 


\section{はじめに}

脳動静脈奇形 (以下 AVM と略す)の手術を安全に行う ため種々の方法が試みられているが，その方法の一つとし て血管内から栄養動脈を塞栓物により閉塞し, 奇形を摘出 する方法がある208)10)11)13)14．われわれは，AVMの栄養 動脈が導出静脈より深部にあり太いもの, 年齢的要素や血 管撮影所見から血管内手術操作が可能と判断された 8 症例 に対して術直前に塞栓術を施行し, 引き続いて開頭術によ る観血的摘出を行った. 術前の塞栓術の利点ならびに問題 点について, われわれの症例結果から検討し, また塞栓術 と観血的手術までの期間についても考察する.

\section{対象および方法}

16 歳から 72 歳までの 8 症例が今回の検討の対象である. 男性 5 例, 女性 3 例であり, AVM の存在部位は側頭部 2 例, シルビウス裂部 2 例, 頭頂部 1 例, 後頭部 1 例, 頭頂 後頭部 1 例，そして脳梁部が 1 例である. またAVMの 臨床的分類を Spetzlerの分類 ${ }^{7)}$ に従って分けると, Grade 1 が 1 例, 2 が 4 例, 4 が 2 例, そして 5 が 1 例であった (Table 1).これら症例に対してまず塞栓術を施行, それ に引き続いて開頭術による観血的 AVM 摘出を行う方針 をとった．塞栓術は，放射線科の神経放射線グループが施 行し, 観血的摘出はわれわれ脳神経外科医が対応した.

塞栓術については Target Therapeutics 社製 Tracker infusion catheter を使用. 塞栓物質としては滝らの開発した ethylene-vinyl-alcohol-copolymer (以下 EVAL と略す) を 用いた ${ }^{11)}$. 塞栓術操作中は局所麻酔下に行われ, 神経学 的所見の頻回の観察のほか, 脳波, 体性感覚脳幹反射のモ ニターを施行した。また塞栓物を注入する前に必ずアミ タール注入試験を行って神経症状の欠損状況を確認したが 当然予測される症状以外の症状発現時には, EVALによ る塞栓は中止することとした。塞栓術によって AVMが 脳血管撮影上完全に消えるのを目標としたが，アミタール 注入試験で重大な症状(麻痺および言語障害)が出たものは その時点で中断，また塞栓術手術の時間が 6 時間以上にな ったもの, さらに操作中 AVMより出血を併発したもの はその時点で中止し直達手術へと移行した. これらの塞栓 術の時間は 2 時間から 6 時間, 平均 4.8 時間であった. 塞 栓術の方法は, AVMの大きさにもよるが, 一本の栄養動 脈に対し EVAL $0.5 \mathrm{~m} l$ を使用. その後造影し AVM の状 況を確認，もし造影されれば再び $0.5 \mathrm{~m} l$ 注入し再度確認 しその栄養動脈からの造影が $90 \%$ 以上消失すれば次の栄 養動脈に対し同様の操作をすることとした．なお直達手術 は従来の方針どおり, AVM を栄養動脈から切り離し, nidus を剥離, 最後に導出静脈を切って摘出することとし
ているが，十分に栄養動脈の塞栓ができたものでは直接 nidusに至り，また部分的塞栓の場合でもすでに塞栓され ている栄養血管に対しては, あえて初めに露出することな く nidus を剥離, 摘出することとした.

\section{結果}

まず塞栓術の結果であるが，脳血管撮影 (digital subtraction angiography一以下 DSA と略す)上, AVM が全 く造影されなくなったものは 2 例 (Case No. 1，7)であり, また 3 例は数本の栄養動脈のうちの 1 2 本が閉塞された が,このうち 2 例ではカテーテルの導入が困難であったた め(Case No. 4, 8), 他の 1 例はアミタール注入により症 状が発現 (Case No. 5) したために塞栓化しえなかった. 残 りの 3 例も 1 例 (Case No. 3) はカテーテル導入不能, 2 例 (Case No. 2, 6) はアミタールテスト陽性のため塞栓術は できていない. なお出血合併をみたのは 2 例 (Case No. 1, 6)であるが, Case No. 6 では操作中にワイヤーにて AVM を損傷し, 急性硬膜下血腫を併発したため, 直ちに直達手 術に移った. Case No. 1 では十分な塞栓が行われたが, それの確認のためDSA 下に栄養動脈内から造影剂を注入 したところ，造影剤の血管外漏出が見られたものである. しかしこの症例では, このとき中等度の頭痛と嘔気を訴え たがそれ以外の神経学的変化はなく, 直達手術時でもわず かな出血が EVAL で硬化したAVM 上に認められた (Table 1).

なお，EVALによる塞栓術にて AVM がDSA 上全く見 られなくなった 2 例と, 栄養血管 2 本のうちの 1 本が完全 に塞栓された症例 (Case No. 4) では, EVAL 注入直後に 施行されたDSA では栄養血管は nidus の直前まで造影が 見られていたが, 直達手術後数日して施行された術後の脳 血管撮影で栄養動脈は起始部まで閉塞しており, また CT でもAVM の摘出部とは別に新たな脳梗塞発生の所見を 呈していた．幸いにして，これらの症例は梗塞部が無症状 領野であったため, 大事には至らなかった。

塞栓術がうまく行われた症例の直達手術は出血も少なく 容易であり, 部分的閉塞に終った症例でも導出静脈より深 部で nidus の内側部から栄養動脈が塞栓化されていれば, 脳表から入る栄養動脈の処理でほぼ無血的に nidus を摘出 することができた。 ただ直達手術の際, 脳表に存在する nidus ならびに導出静脈を手術用顕微鏡下に観察すると, DSA 上全く AVM の造影が見られなかった 2 例でも, 黒 変した nidusに動脈血が周辺部より注ぎ込まているのが認 められ, また nidus を剥離し, かつ導出静脈を切離すると 栄養動脈が拍動しているのが Case No. 7 で認められた. そして，摘出したAVM を触診してみると, EVAL は nidus の導出静脈側で主に塞栓化している印象を与えた。 
Table 1

\begin{tabular}{|c|c|c|c|c|c|c|c|c|c|}
\hline $\begin{array}{l}\text { Case } \\
\text { No. }\end{array}$ & $\begin{array}{l}\text { Age } \\
\text { Sex }\end{array}$ & Location & $\begin{array}{c}\text { Grade } \\
\text { (Spetzler) }\end{array}$ & $\begin{array}{l}\mathrm{Em} \\
|\mathrm{C}|\end{array}$ & $\mid \mathrm{P}$ | & $\mathrm{N}$ & ion & Surgery & Outcome \\
\hline 1 & $16 \mathrm{M}$ & R-parietal & 2 & 0 & & & 0 & yes & excellent \\
\hline 2 & $37 \mathrm{~F}$ & R-Sylvian & 4 & & & $\bigcirc$ & & yes & good \\
\hline 3 & $72 \mathrm{M}$ & R-occipito-parietal & 1 & & & 0 & & yes & excellent \\
\hline 4 & $37 \mathrm{M}$ & R-temporal & 2 & & 0 & & & yes & excellent \\
\hline 5 & $44 \mathrm{~F}$ & corpus callosum & 5 & & 0 & & & yes & died \\
\hline 6 & $59 \mathrm{~F}$ & L-Sylvian & 4 & & & 0 & 0 & yes & poor \\
\hline 7 & $47 \mathrm{M}$ & R-temporal & 2 & 0 & & & & yes & excellent \\
\hline 8 & $45 \mathrm{M}$ & L-occipital & 2 & & $O$ & & & yes & excellent \\
\hline
\end{tabular}

$\mathrm{C}$ : angiographically complete, $\mathrm{P}$ : partial, $\mathrm{N}$ : not capable, H: hemorrhage

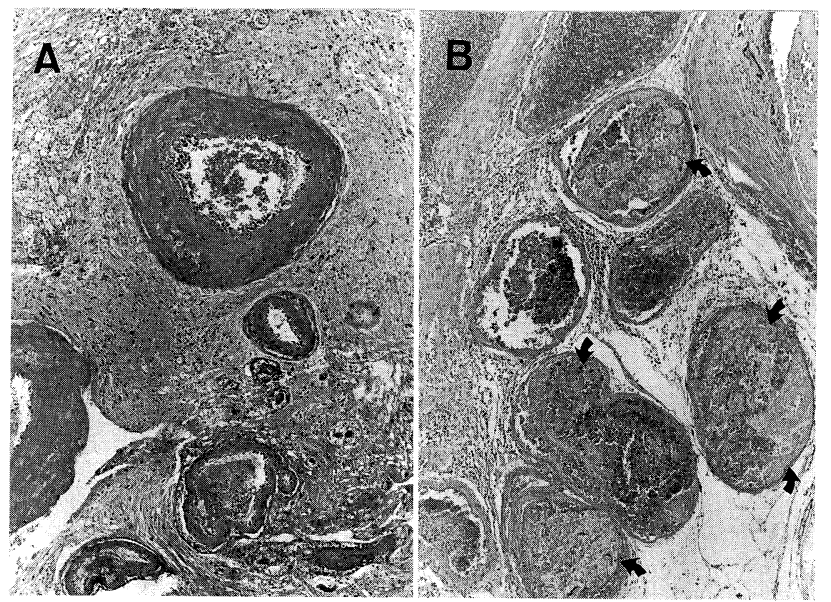

Fig. 1 Histological findings of surgically removed AVM which was completely embolized angiographically demonstrated that embolus (arrow) existed mainly in the nidus and draining veins $(B)$, but there were no emboli in the feeding arteries $(\mathbf{A}) \times 40, \mathrm{HE}$ stain.

特にこのわずかな動脈血の nidusへの流入所見は, 直達手 術でnidus を摘出しておかなければ将来再び大きな AVM へと発展する可能性を示した.

摘出された AVMの組織学的所見では, EVAL が nidus 内を充填している症例はなく, DSA 上全く AVMの造影 がなかった 2 例でも血液と EVAL が混在し，中心部から 導出静脈側にかけて EVAL が認められるが，その nidus の周辺部は血液で充満した状態となっていた(Fig. 1).

\section{<症例 1 > 16歳, 男性.}

野球の練習中に突然頭痛㧍よび鹗気が生じた．その後も 頭痛が存在するために近位を受診し，そこでCT スキャン を受けたところ，右脳室内に出血の生じていることが判明 し紹介を受けて来院した．脳血管撮影を施行したところ， 右後大脳動脈の頭頂後頭枝より栄養される AVM ( Fig.
2A)が認められた，入院 10 日後に，AVMに対し塞栓術を 施行しその後直達手術で摘出することとした。まずDSA の誘導下にカテーテルを栄養動脈の直前まで入れ，造影を 行った. AVMの nidus が造影されすぐ脳底静脈に流出す るのが認められた(Fig. 2B). 引き続いて(アミタールテス トで半盲などの神経欠損症状が出ないことを確認後) EVAL を注入し，nidus の塞栓化を行った．そして再び造 影剤によりAVMの消失状況を確認した。 AVMはかなり 消失するもなお，排出静脈の一部が造影されていたため (Fig. 2C), 再度 EVALを注入し, そして造影を行ったと ころ, 突然患者は頭痛を訴えた。その時の造影所見では, AVM は全く消失していたが, 造影剂の血管外漏出を認め た(Fig. 2D)．CT 施行したところ，AVM の存在したとこ ろに血腫が生じているのが判明 (Fig. 3A)，直ちに開頭術 を施行し硬化した AVM と共に血腫も除去した. 術後経 

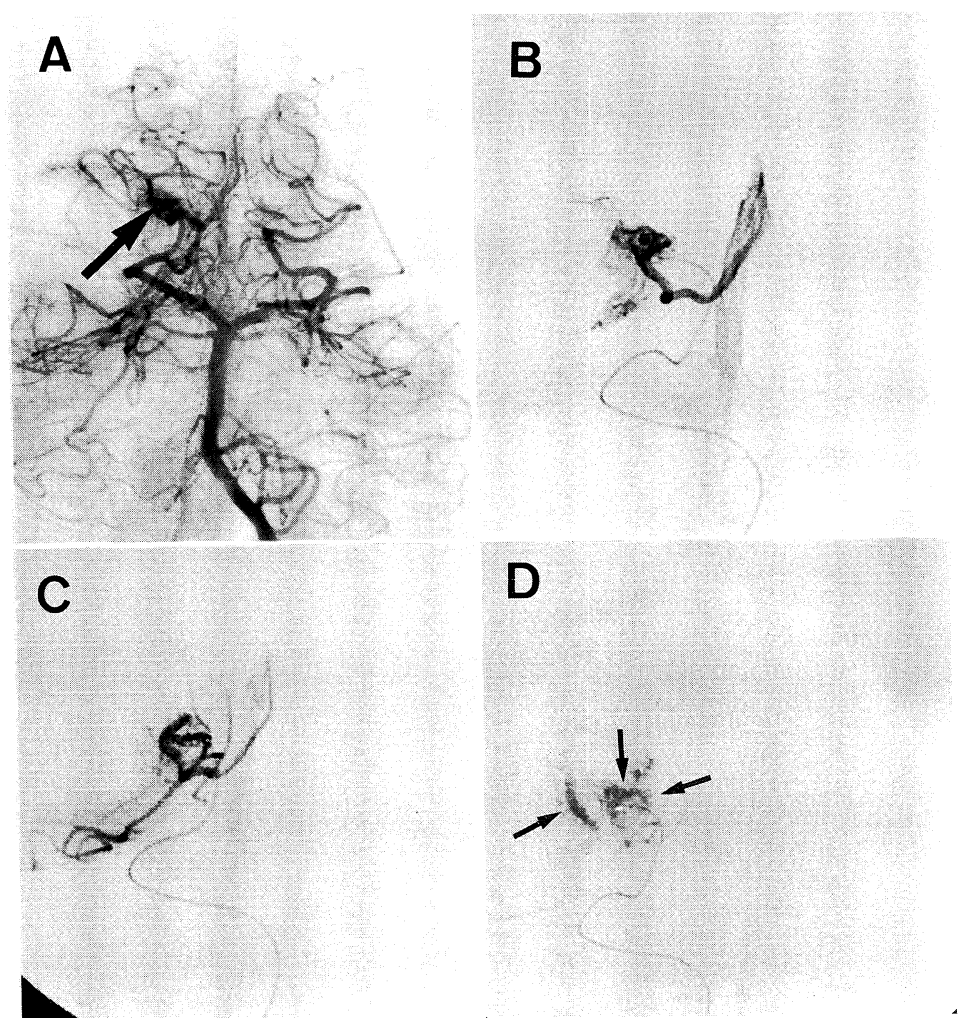

Fig. 2 AVM of Case No. 1 was mainly nourished from the parietooccipital branch of the right posterior cerebral artery (A). Catheterization into the feeding aretery was performed and nidus of AVM was visualized by the injection of contrast material (B). After the injection of $0.5 \mathrm{~m} l$ of EVAL, AVM was partially embolized (C). Although AVM was disappeared by the injection of more $0.5 \mathrm{~m} l$ of EVAL, extravasation was confirmed with angiography (D).

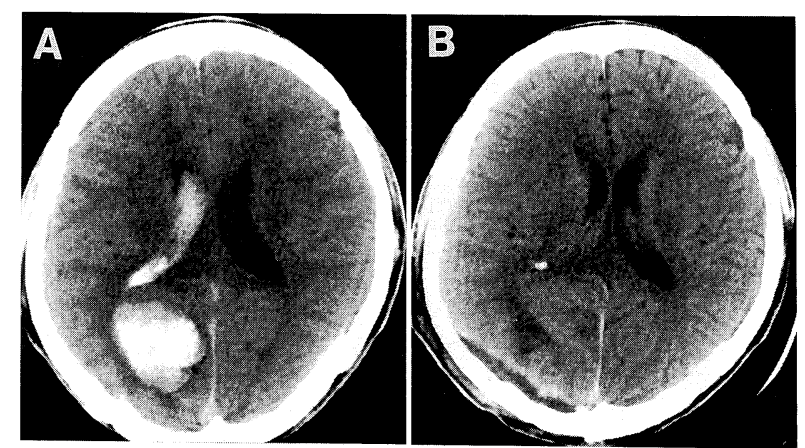

Fig. 3 CT scan performed after the extravasation of contrast material showed new intracerebral hematoma in the posterior parietal region (A). This hematoma was completely removed with AVM by the surgical procedure (B).

過は良好で CT 上わずかに同部位に低吸収域を残したが (Fig. 3B), 神経学的には問題なく, 3 週間後に退院した.
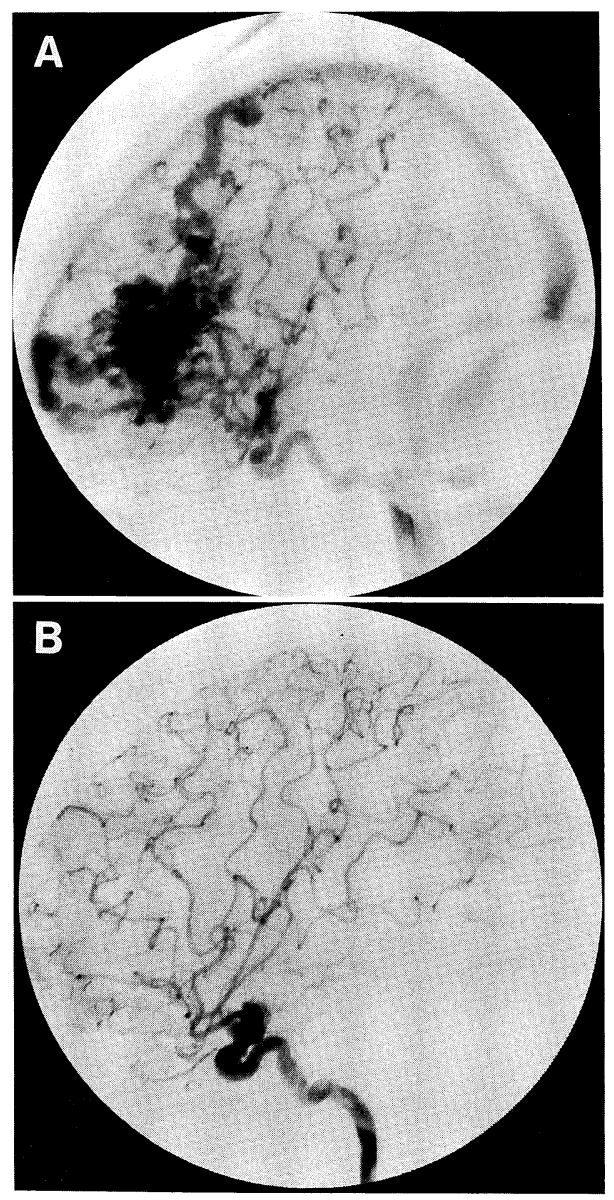

Fig. 4 AVM of Case No. 5 existed in the corpus callosum and was nourished mainly from the anterior cerebral artery (A). Because the AVM was not almost disappeared by the injection of EVAL, it was removed surgically and postoperative angiography showed no AVM (B).

<症例 5> 44 歳, 女性.

7 年前, 5 年前, 2 年前の 3 回にわたってクモ膜下出血, 脳室内出血の既往があり, 水頭症も生じて VP シャントも 施行されている. 出血のたびに手術の検討がなされたが, 患者自身の希望もあり，保存的に処置されてきた。しかし 平成 2 年 11 月に再度出血を起こし救急入院となった. CT 上は脳室内出血となり急性水頭症を起こしていた，脳血管 撮影では前大脳動脈から大量にAVMに流入し，また中 大脳動脈の穿通枝からも栄養されている high flow type (Fig. 4A)であった．これに対し塞栓術を試みたが, 前大 脳動脈より EVAL を注入 $(0.5 \mathrm{~m} l, 0.5 \mathrm{~m} l, 1 \mathrm{~m} l$ の 3 回 $)$ するも，AVMはわずかに縮小したのみであり，また栄養 動脈枝への選択的カテーテル誘導をはかったが不能に終わ った。そのため開頭術を施行，AVM を摘出した，術直後 


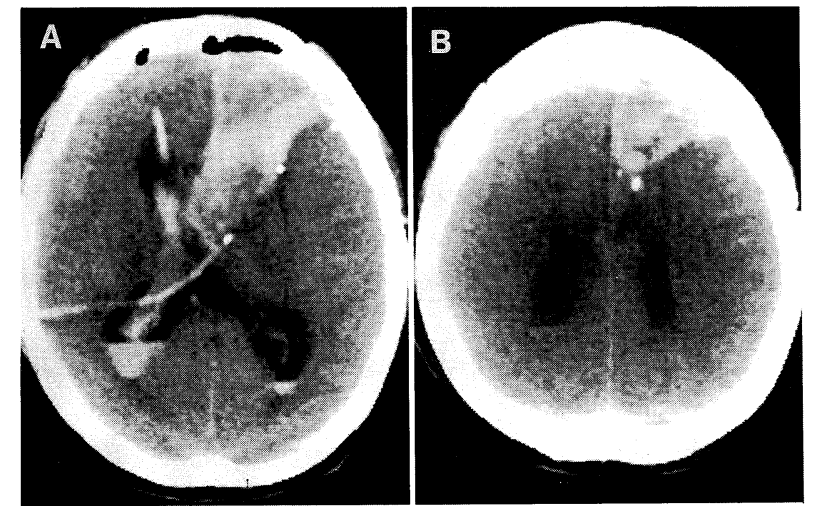

Fig. 5 CT scan performed on the next day of surgery demonstrated intracerebral hematoma $(\mathbf{A}, \mathbf{B})$ due to the suspect of normal perfusion pressure breakthrough after removal of high flow AVM.

は意識も明瞭であったが，翌日になって急速に意識が低下 CT を施行すると AVM 摘出部に出血が認められた Fig. 5).引き続いて脳血管撮影を施行したが AVM は全く消 失しているのが確認された (Fig. 4B). 再度血腫除去のた め開頭したが脳全体は hyperemic となっており術後も脳 の腫脹が強く, 9 日目に死亡した.
$<$ 症例 7> 47 歳, 男性.

1990 年 10 月，全身病攣を起こし，某病院に入院した。 入院時, 左半身麻痺が見られたが，その後徐々に回復した. CTにて明白な出血や梗塞の所見はないが，造影 CT にて 左側頭部に異常所見が見られるとのことで 11 月に紹介さ れてきた. 脳血管撮影にて右後側頭動脈および中側頭動脈 を栄養動脈とする直径 $3.5 \mathrm{~cm}$ 大の AVM であることが判 明した Fig. 6A，B). 明白な出血の既往はないがAVMの 部位から考えて摘出可能と判断, まず栄養動脈からの塞栓 術を計画した. 初めに後側頭動脈に tracker 10 カテーテル を入れ, nidus 直前でアミタール注入試験後に EVAL で 塞栓化し, 続いて中側頭動脈にも同様の操作で EVALに よる塞栓術を施行した. 術中は全くトラブルなく, 塞栓術 後の DSA ではAVM は全く消失しているのが確認され (Fig. 6C)，また後側頭動脈も filling は遅くなっているも のの造影されていることが確認された(Fig. 6D).

当初の方針どおり，この塞栓化したAVMを観血的に 摘出することとした. 開頭し硬膜を切開すると導出静脈, nidus が見られ，さらに栄養動脈も認められたが，本来の AVM の色彩は失われ黒赤色に变化していた．しかしょく 観察してみると, 静脈と同様の色に変化した nidusに周囲

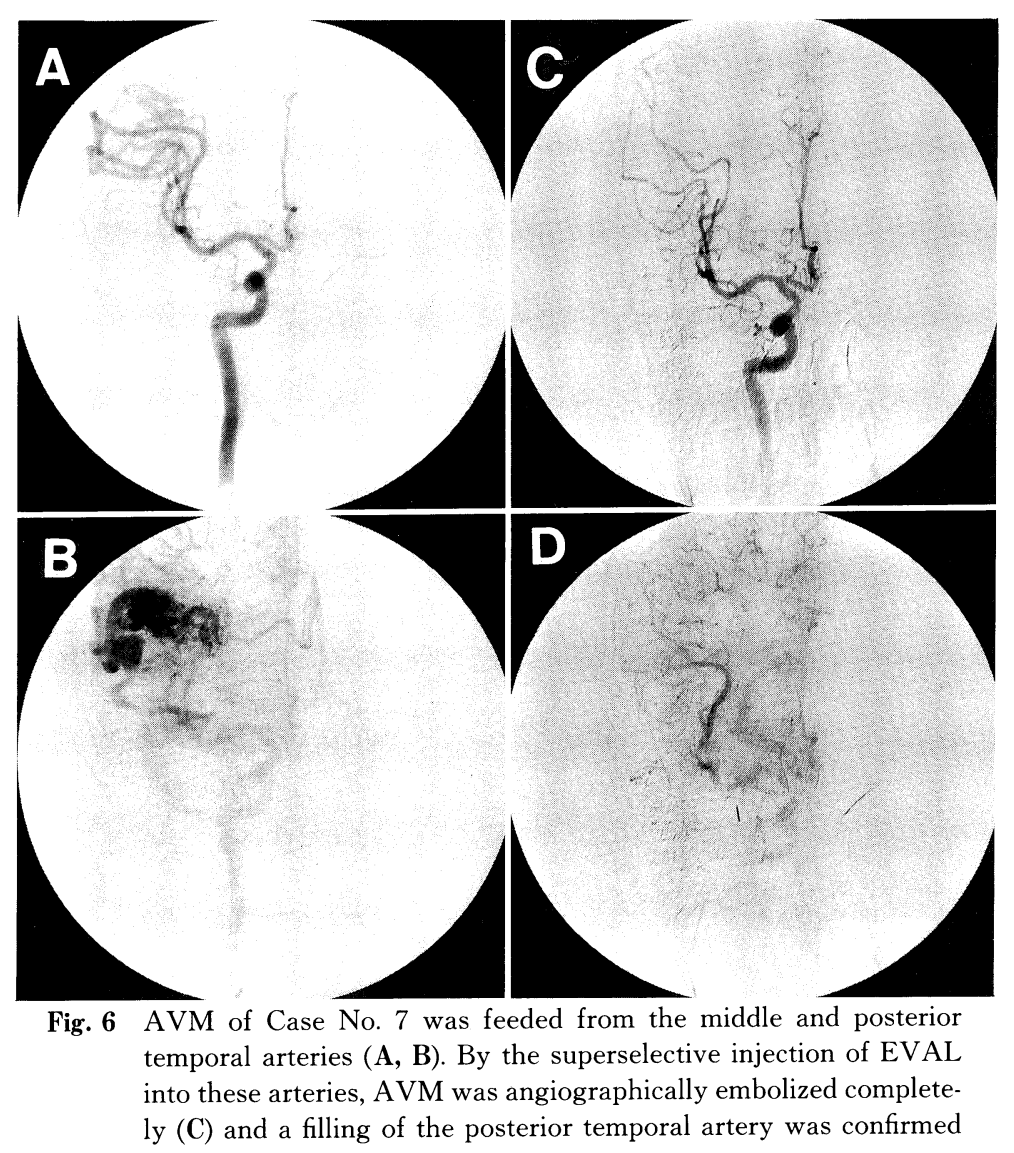

(D). 


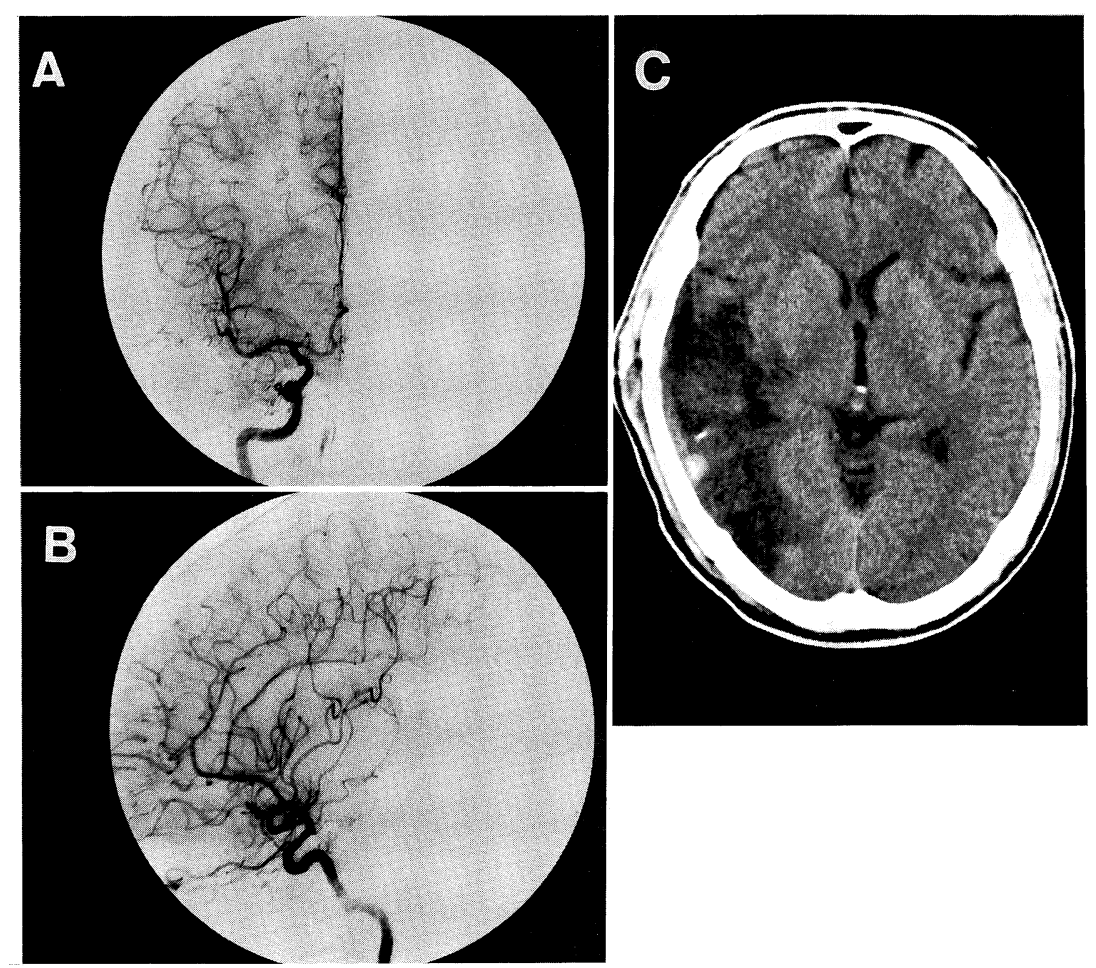

Fig. 7 Postoperative angiography demonstrated disappearance of AVM and occlusion of the right posterior temporal artery (A, B). Postoperative CT demonstrated large infarction in the right temporal lobe and indicated that this infarction was secondary, to occlusion of the right posterior temporal artery $(\mathbf{C})$.

からわずかな動脈血の流入が観察された。血流速度が遅い ため，血管撮影上AVM は造影されなかったものと考え られた。この AVMを nidus から導出静脈切除し, 閉塞さ れた栄養動脈に向かって剥離, 摘出した。

術後の CT では，摘出されたAVM から遠く離れた領 域にまで低吸収值域が出現しているのが確認された（Fig. 7A，B）。また栄養動脈も術直前では nidus 直前にて閉塞し ていたが，術後の撮影ではその起始部まで閉塞しており (Fig. 7C), 明らかに脳を栄養する細小動脈まで血栓化が 逆行性に進行し，その結果，広範な側頭葉の梗塞を招いた と思われた。患者は幸いにして神経学的に異常を示さず退 院した。

\section{考察}

AVM に対する外科的治療を容易なものとするための補 助的手段として, あるいは根本的な治癒を目的とした方法 として, AVMの栄養動脈からの塞栓術が行われるように なった2)810)11)13)14). かつて，この目的として使用される 塞栓物質として silicone ball, poly-vinyl alcohol particeな どの固体を用いるものと isobuthyl-2-cyanoacrylate (IBCA), normobuthyl-cyanoacrylate (NBCA)などの液状
塞栓物が用いられていた1)5)8). しかし血管手術用カテー テルやガイドワイヤーなどが非常に発達し，それに伴って 血管内操作技術も向上, 脳内の動脈にまで誘導できるよう になったことから, 安全に使用できる塞栓物質の開発が望 まれていたが，滝ら ${ }^{11)}$ の手によって EVAL が開発された。 これは従来の液体塞栓物に比し, カテーテルを血管壁に接 着したり, カテーテルを閉塞する危険性が少なく, 熟練を 要する素早い血管内操作を必要とせず, さらに治療対象と なるAVMは栄養動脈内にカテーテルを留置したまま必 要に要じて塞栓物質を注入でき, そして硬化しても柔らか いなどの利点を有する ${ }^{11) 14)}$ 。われわれも，この EVALを 塞栓物質として用いた。

このEVALによるAVM の塞栓術の最大の利点は栄養 動脈のみならず nidus そのものが塞栓化されることであろ う. EVALによって塞栓された AVMの手術は極めて容 易なものであった．つまり多くの AVM で導出静脈が栄 養動脈よりも表面にあるため, 太い導出静脈を温存しなが らの nidusの剥離には困難を伴うが, 十分に塞栓されてい れば導出静脈を最初に処理して nidusを摘出することも容 易である.さらに nidus を摘出しても白質周囲に動脈とも 静脈ともつかない小さな血管から出血し, これの止血に困 
難を感じる場合が多いが，十分に塞栓化されたAVMで はこれらの血管も塞栓により充填されており，この血管か らの出血もほとんど見ることはなかった。手術によって摘 出するという観点からのみみれば，EVAL による塞栓術 は非常に有用なものであった.

しかし，合併症という点からみると問題がある，という のがわれわれの少ない経験からの結論である. 塞栓術操作 中の出血は技術的な問題であるが，予期した範囲よりも広 い領域で脳梗塞が生じたのは極めて重大な問題点といわざ るをえない. 今回，われわれはアミタール注入試験で症状 の出現のないことを確認の上 EVALを注入しているが, 術後 CT では広範に低吸収值域が広がり，また塞栓術中の 血管撮影では栄養動脈は nidusの所まで造影されていたの が, 術後 follow-up の造影では起始部まで閉塞し血栓が逆 行性に生じてきたことを示していた。そのためその動脈に よって栄養されていた領域が梗塞に陥ったものである.わ れわれの症例では, 栄養動脈の閉塞が非優位脳のしかも無 症状領域に限局していたため大きな症状は出現しなかった. だが, AVMの塞栓術が最も期待されるのは優位脳の eloquent area に存在するものや，深部の大きな AVMである. 定藤ら ${ }^{6)}$ はアミタール注入試験を行って症状発現がなくて も $27 \%$ EVAL 注入後に症状発現をみたと報告している し, 兵藤ら ${ }^{4)} も 10$ 例の AVM に対し 21 回の塞栓術を施行 しているが，5回の合併症のあったことを報告している. 栄養動脈といっても, nidus に至るまで無数の枝を出して 脳を栄養し, nidusを越えてからも脳を栄養する動脈とな る、たた AVMによる盗血のために血管造影上これれら の脳を栄養する細動脈部分が写らないだけであり, skillful にAVM を外科的に摘出された症例の術後血管撮影で は，栄養動脈になっていた血管が本来の脳を栄養する動脈 に変わっていることを考えると，この栄養動脈を閉塞する ことは危険性が高く, 現時点では非優位脳の non-eloquent areaに限局したものにのみ安全に行いうるという印象で ある。またどの程度の大きさの AVMにどれだけの量の EVAL を注入したらよいかという問題がある. 多すぎれ ば当然梗塞を誘発するし，少なすぎれば，AVMは閉塞さ れない. われわれは $0.5 \mathrm{ml}$ を注入し, 造影を施行, AVM の消失程度をみていくという方法をとったが，多くの使用 者も同様の方法をとっており，決まったものはない状況で ある ${ }^{12)}$.

次に,この塞栓術後のどの時期にAVMを摘出するか という問題がある。これには塞栓術をAVM 手術のため の術前処置として行うのか，あるいはAVM に対する非 観血的手術としてなされるのかによって根本的に異なる. 前者の場合, なお定まった意見はない. われわれは, この 塞栓術後すぐに観血的に AVM 摘出を行う方針をとって
きた. その理由の一つに, 不十分な塞栓術の後, 大出血を きたしたという過去の経験(この症例は塞栓物としてスポ ンゼル®を使用した)がある。同様の経験は多いものと思 われるが，それに関するまとまった報告はない。

Spetzler ら ${ }^{9)}$ は, transfemoral embolization によって大 きなAVMを小さなものにした後, 数日から数週間後に 破裂した経験について述べ, AVMの治療の目標は完全な 閉塞であるべきであると強調している，部分的に閉塞させ hemodynamic stress に変化の生じたAVM は非常に破裂 しやすい環境にあると言わねばならず，もし保存的に経過 を見るなら徹底した血圧の管理など，残存 AVM に対す る hemodynamic stress を軽減させるような努力が極めて 重要であろう.

nidus が造影されなくなった場合, 観血的に摘出する必 要があるか否かという問題がある. われわれはわずか 2 例 しか経験がないがその時の印象では, やはり観血的に摘出 した方が良い，というものであった。つまり2例ともに手 術用顕微鏡下にAVMの nidus を見ると, 周囲からわずか ではあるが, 動脈血が nidus 内へ流れ込んでいるのが観察 され，後日再びAVM が造影されるようになってくると いう印象を与えた．塞栓の永続性について，AVMが完全 に閉塞されたものでは経過を見るという意見 4)12)14)も多い が，ほとんど消失した AVM が再開通を起こしてきたと いう報告 ${ }^{3)}$ も見られ，観血的摘出が患者にとって大きな負 担とならない部位の AVM ならば，血管撮影で消失して いても摘出しておくのが最良の方法と考える.

\section{文献}

1) Bernstein A, Kricheff II: Catheter and material selection for transarterial embolization; Technical consideration. II. Materials. Radiology 132: 631-639, 1979

2) Debrun G, Vinuela F, Fox A, et al: Embolization of cerebral arteriorenous malformations with bucrylate. Experience in 46 cases. J Neurosurg 56: 615-627, 1982

3）米田 隆, 根来 真, 宮地 茂, ほか: 脳動静脈奇形の血 管内手術一塞栓材料の比較検討. 脳卒中の外科 20: 319322,1992

4）兵藤明夫, 上村和也, 桶口修, ほか：Intravascular surgery を応用した脳動静脈奇形の治療一術前導入動脈閉塞 術と塞栓術の有用性と問題点一. 脳卒中の外科 20: 301307, 1992

5) Pelz DM, Fox AJ, Vinuela E, et al: Preoperative embolization of brain, AVMs with isobutyl-2-cyanoacrylate. AJNR 9: $757-764,1988$

6) 定藤章代, 滝 和郎, 西 正吾, ほか：血管内手術法にお ける誘発試験の有用性とその問題点. 第 6 回日本脳神経血 管内手術研究会演題抄録集, 1990, p 33

7) Spetzler RF, Martin NA: A proposed grading system for arteriorenous malformations. J Neurosurg 65: 476-483, 1986

8) Spetzler RF, Martin NA, Carter LP, et al: Surgical management of large AVMs by staged embolization and operative 
excision. J Neurosurg 67: 17-28, 1987

9) Spetzler RF, Hargraves RW, McCormick PW, et al: Relationship of perfusion pressure and size to risk of hemorrhage from arteriovenous malformations. J Neurosurg 76: 918-923, 1992

10）高橋 明，吉本高志，菅原孝行，ほか：脳動静脈奇形に対 する新しい液体塞栓療法の経験一エストロゲンアルコール とポリ酢酸ビニール併用療法一. 脳卒中の外科 18: 453457, 1990

11) Taki W, Yonekawa $Y$, Iwata $H$ : A new liquid material for embolization of arteriorenous malformations. AJNR 11: $163-168,1990$

12) 滝 和郎: personal communication. 1992

13) Vinters HV, Lundie MJ, Kaufmann TCE: Long-term pathological treated by embolization with bucrylate. $N$ Engl J Med 314: 477-483, 1986

14）山下耕助, 米川泰弘, 滝 和郎, ほか: 治療困難な脳動静 脈奇形に対する ethylene-vinyl-alcohol-copolymer (EVAL) による塞栓術. 脳卒中の外科 18: 448-452, 1990 